\title{
EVALUATION OF RISK FACTORS OF PATIENTS WITH CHRONIC LOW BACK PAIN APPLYING TO THE PHYSICAL THERAPY AND REHABILITATION OUTPATIENT CLINIC
}

\author{
Ayşe Berhoğlu Barut ${ }^{1} \bowtie$ (iD) \\ ${ }^{1}$ Md, Private Eastern Anatolia Hospital, Department of Physical Medicine and Rehabilitation, Elazig, Turkey.
}

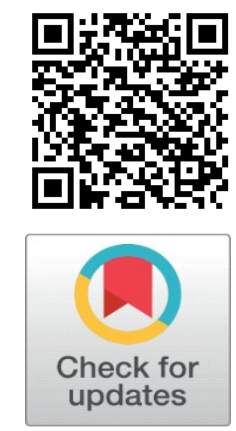

Received 5 September 2021

Accepted 18 September 2021

Published 30 September2021

\section{CorrespondingAuthor}

Ayșe Berhoğlu Barut,

ayse_berh@hotmail.com

DOI

10.29121/granthaalayah.v9.i9.2021. 4270

Funding: This research received no specific grant from any funding agency in the public, commercial, or not-for-profit sectors.

Copyright: (C) 2021 The Author(s). This is an open access article distributed under the terms of the Creative Commons Attribution License, which permits unrestricted use, distribution, and reproduction in any medium, provided the original author and source are credited.

\section{ABSTRACT}

Objectives: To investigate the risk factors affecting these pains in patients with low back pain.

Methods: In this retrospective observational study, the patients were asked about their age, gender, occupation, marital status, educational status, economic status and smoking status. The duration of low back pain was measured in months and the severity was 0-no pain and 10-unbearable pain on a $10 \mathrm{~cm}$ line with the Visual Analogue Scale (VAS) and the data were recorded.

Results: Of 224 patients, 144 (64.3\%) were female and 80 (35.7\%) were male. The most common causes of chronic low back pain were lumbar spondylosis (120 patients, 53.6\%) and discal hernia (68 patients, 30.4\%). It was determined that the rate of low back pain was $72.3 \%$ higher in patients aged 60 and over. It was observed that as the education level increased, the rate of low back pain decreased significantly. $57.1 \%$ of the patients were found to be low-income; low back pain rate was higher in this group compared to the others. When we examined the relationship between smoking and low back pain, it was determined that $60.7 \%$ of the patients with low back pain were smoking.

Conclusion: A significant relationship was found between low back pain and an advanced age female patient, low economic level, low education level, and smoking.

Keywords: Physical Therapy and Rehabilitation Clinic, Low Back Pain, Risk Factors

\section{INTRODUCTION}

Low back pain is a symptom that up to $85 \%$ of the world's population has experienced at least once in their lives and is a very common symptom in medicine. Epidemiological studies evaluating the frequency of low back pain in adulthood in the world reveal that the prevalence is $12 \%$ instantaneously, $23 \%$ monthly, 38\% annually, and approximately 40\% throughout life Manchikanti et al. (2014). The majority of low back pain is of mechanical origin and occurs as a result of excessive use, strain or traumatization of the spine and surrounding structures Chou and Shekelle (2010). In the vast majority of this type of pain, the specific etiology cannot be determined exactly; disc, paraspinal muscles, ligaments, etc. degeneration, stretching and sprains in tissues are held responsible for pain Chou et al. (2009). Generally, pain increases with physical activity, standing or sitting for a long time, and decreases with rest Patel et al. (2013). This type of pain, which occurs mostly as a result of degenerative and traumatic problems, is often localized to the waist, but it can also spread to the hips and thighs from time to time Deyo et al. (1992). 
Risk factors affecting low back pain vary depending on the structure of societies, income levels and living conditions. In our study, we aimed to determine the risk factors of patients with low back pain, which causes economic, psychological and social problems.

\section{MATERIALS AND METHODS \\ 2.1. STUDY DESIGN AND PATIENTS}

A total of 224 patients who applied to the Elazı̆̆ Private Doğu Anadolu Hospital Physical Therapy and Rehabilitation Polyclinic between February 2019 and August 2021 with the complaint of chronic low back pain and whose etiological cause was determined were included in our study. The patients with nonspecific low back pain lasting longer than 12 weeks and without neurological deficit were evaluated. Patients with persistent or severe low back pain, pregnant women, those who had previous surgery, structural anomalies, spinal cord compression, severe instability, severe osteoporosis, severe cardiovascular or metabolic disease, and acute infection were excluded from the study.

\subsection{DATA COLLECTION}

Detailed anamnesis of all patients was taken and physical examinations were performed. Patients' age, gender, occupation, marital status, education, economic status and smoking information were recorded. While the education status of the patients was questioned, their most recent education levels were recorded. For the economic situation, the self-reported answers of the patients were taken into account, without any income level. The duration of low back pain was measured in months and the severity was measured on a $10 \mathrm{~cm}$ line as 0 - no pain and 10 unbearable pain with the Visual Analogue Scale (VAS).

\subsection{STATISTICAL ANALYSIS}

Continuous variables were presented as mean \pm SD and categorical data as numbers and percentages. For statistical analysis, SPSS program (version 22.0, IBM, USA) was used.

\section{RESULTS}

Of 224 patients, 144 (64.3\%) were female and 80 (35.7\%) were male. The most common causes of chronic low back pain were lumbar spondylosis (120 patients, $53.6 \%$ ) and discal hernia (68 patients, 30.4\%). The distribution of 224 patients diagnosed with low back pain is shown in Table 1.

\begin{tabular}{|ccc|}
\hline Table 1 Distribution of etiological factors causing low back pain \\
\hline Patient's complaint & Number & $\mathbf{\%}$ \\
\hline Lumbar spondylosis & 120 & 53.6 \\
\hline Discal hernia & 68 & 30.4 \\
\hline Spinal stenosis & 20 & 8.9 \\
\hline Sacroiliac joint degeneration & 9 & 4.0 \\
\hline Spondylolisthesis & 7 & 3.1 \\
\hline
\end{tabular}


When we examined the risk factors affecting low back pain, 62 (27.7\%) patients under the age of 60 had low back pain, while $162(72.3 \%)$ patients aged 60 and over had low back pain. When the relationship between low back pain and the occupations of the patients was examined, it was found to be significantly higher in housewives, but lower in students. It was observed that as the education level increased, the rate of low back pain decreased significantly. While 167 (74.5\%) of 224 patients were married, 57 (25.5) patients were single, and the frequency of low back pain was higher in married people than singles. Again, the frequency of low back pain was found to be higher in women who had $\geq 1$ pregnancy compared to women who had $\leq 1$ pregnancies $(68.1 \%$ and $31.9 \%$, respectively). $57.1 \%$ of the patients were found to be low-income; low back pain rate was higher in this group compared to the others. When we examined the relationship between smoking and low back pain, it was found that $60.7 \%$ of the patients with low back pain were smoking (Table 2).

\begin{tabular}{|c|c|c|}
\hline Risk factor & Number & $\%$ \\
\hline \multicolumn{3}{|l|}{ Age (years) } \\
\hline 60 & 62 & 27.7 \\
\hline$\geq 60$ & 162 & 72.3 \\
\hline \multicolumn{3}{|l|}{ Gender } \\
\hline Female & 144 & 64.3 \\
\hline Male & 80 & 35.7 \\
\hline \multicolumn{3}{|l|}{ Marital status } \\
\hline Married & 167 & 74.5 \\
\hline Single & 57 & 25.5 \\
\hline \multicolumn{3}{|l|}{ Pregnancy status } \\
\hline$\leq 1$ & 46 & 31.9 \\
\hline$\geq 1$ & 98 & 68.1 \\
\hline \multicolumn{3}{|l|}{ Job } \\
\hline Housewife & 125 & 55.8 \\
\hline Officer & 32 & 14.3 \\
\hline Retired & 56 & 25 \\
\hline Student & 11 & 4.9 \\
\hline \multicolumn{3}{|l|}{ Education level } \\
\hline Primary school & 104 & 46.4 \\
\hline High school & 88 & 39.3 \\
\hline University & 32 & 14.3 \\
\hline \multicolumn{3}{|l|}{ Income status } \\
\hline Low & 128 & 57.1 \\
\hline Middle & 62 & 27.7 \\
\hline
\end{tabular}




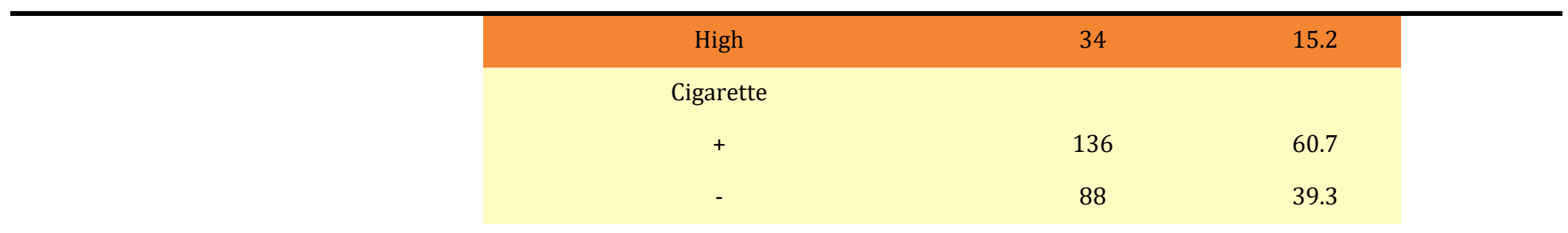

\section{DISCUSSION}

In the general population, $70-80 \%$ of the entire world population experiences low back pain at least once in their lifetime. Low back pain is a health problem with significant socioeconomic effects. It is the most common cause of musculoskeletal problems in the working population Andersson (1999). A study evaluating incidence, prevalence, and years in 195 countries found that low back pain the leading cause of productivity loss worldwide Disease et al. (2018).

Bejia et al. (2005) found the lifetime prevalence of low back pain to be $57.7 \%$ and the prevalence of chronic low back pain to be $12.8 \%$ in a study they conducted on 350 hospital workers. In their study in which they examined the risk factors associated with low back pain, they emphasized that advanced age and female gender were important for low back pain. A systematic review of 165 studies from 54 countries showed that the point prevalence of low back pain was $11.9 \%$ (SD 2) and the 1-month prevalence was $23.3 \%$ (SD 29), and it was most common in women aged 40-80 years Hoy et al. (2012). In our study, low back pain was detected more frequently in elderly female patients, and this aspect was compatible with the literature.

The etiology of low back pain is not known exactly. The studies suggest that modifiable risk factors may play a role in the development of low back pain Strine et al. (2007). However, current evidence for the role of smoking in low back pain is unclear. One of the two reviews on the relationship between smoking and low back pain suggested a relationship between smoking and low back pain Goldberg et al. (2000),while the other reported unclear findings Leboeuf-Yde (1999). Feldman et al. (1999) in their study in which they investigated the risk factors for low back pain, reported that low back pain was seen approximately 2.5 times more in smokers. In a meta-analysis, it was shown that smokers have a higher prevalence and incidence of low back pain than non-smokers Shiri et al. (2010). In our study, low back pain was found to be increased in smokers, and our findings were found to be consistent with the literature.

Studies have shown that occupational factors are associated with low back pain. Matsui et al. (1997) found that the point prevalence of low back pain was 39\% in manual workers and only $18.3 \%$ in sedentary workers. In this study, it was shown that the lifetime prevalence of low back pain is related to working conditions, with the highest risk in heavy lifters.

Low educational status has been shown to be one of the risk factors associated with low back pain. This relationship is due to the fact that people with low education levels generally work in occupational groups that require heavy physical activity Dionne et al. (2001). Burdorf and Sorock (1997) found that low education level, smoking addiction and advanced age were associated with low back pain. In a study conducted in Russia, it was shown that people with low education levels have significantly more low back pain complaints Toroptsova et al. (1995). In another study, it was shown that there was an inverse relationship between social status and the occurrence of low back pain Latza et al. (2000). 


\section{CONCLUSION}

According to our findings, a significant relationship was found between low back pain, elderly female patient, low economic level, low education level and smoking. We think that the frequency of low back pain, which causes financial loss and hinders daily life activities, can be reduced to some extent by taking measures to reduce the identified risk factors.

\section{INFORMED CONSENT}

Written and oral informed consent was obtained from all individual participants included in the study. Additional informed consent was obtained from all individual participants for whom identifying information is included in this manuscript.

\section{AVAILABILITY OF DATA AND MATERIALS}

The datasets used and analyzed during the current study are available from the corresponding author on reasonable request

\section{CONFLICT OF INTEREST}

The authors declare that there are no conflicts of interests.

\section{ETHICAL APPROVAL}

All procedures in this study involving human participants were performed in accordance with the 1964 Helsinki Declaration and its later amendments (Code: 2021/01.12).

\section{REFERENCES}

Andersson GB. (1999). Epidemiological features of chronic low-back pain. Lancet:14;354(9): 581-85. Retrieved from https://doi.org/10.1016/S01406736(99)01312-4

Bejia I, Younes M, Jamila HB, Khalfallah T, Ben Salem K, Touzi M, et al. (2005) Prevalence and factors associated to low back pain among hospital staff. Joint Bone Spine;72(3):254-9. Retrieved from https://doi.org/10.1016/j.jbspin.2004.06.001

Burdorf A, Sorock G. (1997) Positive and negative evidence of risk factors for back disorders. Scand J Work Environ Health ;23(4):243-56. Retrieved from https://doi.org/10.5271/sjweh.217

Chou R, Fu R, Carrino JA, Deyo RA. (2009) Imaging strategies for low-back pain: systematic review and meta-analysis. Lancet ;373(9662):463-72. Retrieved from https://doi.org/10.1016/S0140-6736(09)60172-0

Chou R, Shekelle P. (2010) Will this patient develop persistent disabling low back pain? JAMA ;303(13):1295-302. Retrieved from https://doi.org/10.1001/jama.2010.344

Deyo RA, Rainville J, Kent DL. (1992) What can the history and physical examination tell us about low back pain? JAMA ;268(6):760-5. Retrieved from https://doi.org/10.1001/jama.268.6.760 
Dionne CE, Von Korff M, Koepsell TD, et al. (2001) Formal education and back pain: a review. Journal of Epidemiology and Community Health Jul;55(7):455-68. Retrieved from https://doi.org/10.1136/jech.55.7.455

Disease GBD, Injury I, Prevalence C. (2018) Global, regional, and national incidence, prevalence, and years lived with disability for 354 diseases and injuries for 195 countries and territories, 1990-2017: a systematic analysis for the Global Burden of Disease Study 2017. Lancet ; 392: 1789-858. Retrieved from https://doi.org/10.1016/S0140-6736(18)32279-7

Feldman DE, Rossignol M, Shrier I, Abenhaim L. (1999) Smoking. A risk factor for development of low back pain in adolescents. Spine ;24(23):2492-6. Retrieved from https://doi.org/10.1097/00007632-199912010-00011

Goldberg MS, Scott SC, Mayo NE. (2000) A review of the association between cigarette smoking and the development of nonspecific back pain and related outcomes. Spine (Phila Pa 1976) ;25:995- 1014. Retrieved from https://doi.org/10.1097/00007632-200004150-00016

Hoy D, Bain C, Williams G, et al. (2012) A systematic review of the global prevalence of low back pain. Arthritis Rheum ; 64: 2028-37. Retrieved from https://doi.org/10.1002/art.34347

Latza U, Kohlmann T, Deck R, et al. (2000) Influence of occupational factors on the relation between socioeconomic status and self-reported back pain in a population-based sample of German adults with back pain. Spine Jun 1;25(11): 1390-7. Retrieved from https://doi.org/10.1097/00007632200006010-00011

Leboeuf-Yde C. (1999) Smoking and low back pain. A systematic literatüre review of 41 journal articles reporting 47 epidemiologic studies. Spine (Phila $\mathrm{Pa}$ 1976). 24:1463-70. Retrieved from https://doi.org/10.1097/00007632199907150-00012

Manchikanti L, Singh V, Falco FJ, Benyamin RM, Hirsch JA. (2014) Epidemiology of low back pain in adults. Neuromodulation ;17 Suppl 2:3-10. Retrieved from https://doi.org/10.1111/ner.12018

Matsui H, Maeda A, Tsuji H, et al. (1997) Risk indicators of low back pain among workers in Japan: Association of familial and physical factors with low back pain. Spine ;22(11):1242-8. Retrieved from https://doi.org/10.1097/00007632-199706010-00014

Patel S, Friede T, Froud R, Evans DW, (2013) Underwood M. Systematic review of randomized controlled trials of clinical prediction rules for physical therapy in low back pain. Spine (Phila Pa 1976) ;38(9):762-9. Retrieved from https://doi.org/10.1097/BRS.0b013e31827b158f

Shiri R, Karppinen J, Leino-Arjas P, Solovieva S, Viikari-Juntura E. (2010) The association between smoking and low back pain: a meta-analysis. Am J Med. ;123(1):87.e7-35. Retrieved

https://doi.org/10.1016/j.amjmed.2009.05.028

Strine TW, Hootman JM. (2007) US national prevalence and correlates of low back and neck pain among adults. Arthritis Rheum. 57:656-65. Retrieved from https://doi.org/10.1002/art.22684

Toroptsova NV, Benevolenskaya LI, Karyakin AN, et al. (1995)'Cross sectional' study of low back pain among workers at an industrial enterprise in Russia. Spine ;20(3) :328-32. Retrieved from https://doi.org/10.1097/00007632199502000-00012 